\title{
A Content Analysis of Papers Published by the Lecturers of the Faculty of Sport and Physical Education for the Last Three Years in Journal of Anthropology of Sport and Physical Education
}

\author{
Dragan Bacovic ${ }^{1}$ \\ 'University of Montenegro, Faculty for Sport and Physical Education, Niksic, Montenegro
}

\begin{abstract}
Journal of Anthropology of Sport and Physical Education (JASPE) is a scientific journal that exists for three years and has so far released 107 scientific papers in 7 editions. Papers of lecturers from Faculty for sport and physical education were classified in this paper by the method of content analysis. In last three years they have published 69 papers in total which are classiffied in this paper by these areas: anthropology, sports marketing, papers which analyze the content and other papers. The most published papers are from area of anthropology, 35 in total. This research can be useful for further theoretical research, as well as for theoreticians.
\end{abstract}

Key words: Content Analysis, JASPE, Niksic

\section{Uvod}

Jaspe je štampani i elektronski časopis koji, uz korišćenje savremenih metoda, ima za cilj predstavljanje naučnih saznanja o antropologiji i fizičkom vaspitanju stručnoj i naučnoj javnosti. Od oktobra 2017. do danas objavljeno je sedam izdanja časopisa. JASPE karakteriše otvoren pristup, brzo vrijeme objavljivanja, recenziranje od strane iskusnih naučnih istraživača, zajednički forum i komentarisanje članaka, medijsku pokrivenost u zemlji i svijetu, te vidljivost i uticaj u naučnim bazama radova.

Jaspe izlazi četiri puta godišnje: u januaru, aprilu, julu i oktobru. Kao multidisciplinarni časopis, objavljuje originalne naučne radove, pregledne članke, kratke izvještaje, recenzije, kao i pozive i nagrade u oblasti antropologije sporta i fizičkog vaspitanja. Prekriva svih pet aspekata iz oblasti antropologije i sporta: kulturne, globalne, biološke, jezičke i medicinske.

JASPE izdaje "Montenegrosport", u saradnji sa Fakultetom za sport i fizičko vaspitanje Univerziteta Crne Gore i Crnogorskom sportskom akademijom. Glavni urednik je Bojan Mašanović sa Univerziteta Crne Gore, dok urednička mjesta po oblastima pokrivaju: Miomir Maroš sa Univerziteta Crne Gore (kulturna antropologija), Kubilay Ocal sa Mugla Univerziteta iz Turske (Globalna antropologija), Dušan Stupar sa Ecudons Univerziteta iz Srbije (Fizička antropologija), Tatjana Jovović sa Univerziteta Crne Gore (Lingvistička antropologija) i Nina Đukanović sa Univerziteta u Beogradu (Medicinska antropologija).

\section{Metod}

Za ovo istraživanje korišćena je metoda analize sadržaja. Ova metoda kvantitativno i kvalitativno sistematizuje novinarske oblike komunikacije, pri čemu se, za obradu podataka, koristi statistička metoda i metoda zbrajanja i deskripcije. U ovom radu korišćena je metoda zbrajanja i deskripcije. Jedinica analize sadržaja u ovom radu su naučni radovi predavača sa Fakulteta za sport i fizičko vaspitanje objavljeni u "Journal of Anthropology of Sport and Physical Education”, u period između 2017. i 2019. godine. U ovom periodu predavači sa Fakulteta za sport i fizičko vaspitanje' iz Nikšića su objavili 69 radova.

\section{Montenegro}

Sport

\section{Correspondence:}

\section{Bacovic}

University of Montenegro, Faculty for Sport and Physical Education, Narodne omladine bb, 81400, Niksic, Montenegro E-mail:dragibacovic1@gmail.com 
Radovi su klasifikovani po oblastima sportskih nauka na sljedeće oblasti: antropologiju, sportski marketing, radove koji se bave analizom sadržaja objavljenih radova i ostale radove.

\section{Rezultati}

Antropologija je u JASPE-u bila zastupljena kroz sljedeće radove: „Relationship between arm span measurements and body height in Dinaric Alpes population: a systematic review" (Masanovic, 2017), „Differnces in the morphological characteristics and body compositions of footbal players FC Trepca ' 89 and FC Prishtina in Kosovo (Gardasevic, Bjelica, Popovic, Vasiljevic, \& Milosevic, 2017), „Differences in the morphological characteristics and body composition of football players in Montenegro“ (Corluka, \& Vasiljevic, 2018), „Differences in the morphological characteristics and body composition of football players FC Buducnost and FC Mladost in Montenegro" (Gardasevic, Bjelica, Popovic, Vasiljevic, \& Milosevic, 2018), „Differences in the morphological characterictics and body composition of football players FC Sutjeska and FC Mladost in Montenegro“ (Bjelica, Gardasevic, \& Vasiljevic, 2018), „Differences in the morphological characteristics and body compositions of handball players WHC Levalea in Montenegro and WHC Grude in Bosnia and Hercegovina" (Vukotic, Corluka, Vasiljevic, \& Bubanja, 2018), „Meta-analyze of the scientific papers on the effects of the preparation period on the basic motor skills of the cadet football players" (Vasiljevic, 2017), „Self-reported and objectively measured physical activity of males from 50 to 69 years old“ (Mitrovic, 2018), „Comaparative study of morphological characteristics and body composition between basketball players from second leagues in Montenegro and Serbia“ (Vukasevic, Vukotic, \& Masanovic, 2018), „Comparative study of anthropomertic measurements and body composition between the basketball player first and second league in Montenegro" (Vukasevic, Spaic, \& Masanovic, 2018), „Body height and its estimation utilizing arm span measurements in adolescents from nothern region in Montenegro“ (Bubanja, 2018), „Body height and its estimation utilizing arm span measurements in male and female adolescents from nothern region in Montenegro“ (Vukotic, 2018), „Differnces in the morphological characteristics and body compositions of football players FC Trepca ' 89 and FC Pristina in Kosovo" (Gardasevic, Bjelica, Vasiljević, Sermaxhaj, \& Arifi, 2018), „Body Height and its estimation utilizing arm span measurements in male and female adolescents from Danilograd and Cetinje" (Vukotic, 2018), Self-Reported and Objectively Measured Physical Activity of Males from 50 to 69 Years Old“ (Radulovic, 2018), „Body composition and anthropometric measures of footballers, cup winners of Montenegro and Bosnia and Hercegovina" (Bjelica, Gardasevic, Vasiljevic, \& Corluka, 2018), „Relationship between arm span measurements and body height in Pljevlja“ (Mitrovic, 2018), „Comparative study of anthropometric measurements and body compositions between different level of competition" (Masanovic, Spaic, \& Vukasevic, 2018), Differences in anthropometric characteritics between elite soccer and basketball players" (Masanovic, Vukcevic, \& Spaic, 2018), „Body height and its assessment by using the arm span of adolescents from the Montenegrin municipalities of Berane and Pljevlja“ (Bubanja, 2018), „Differnces in anthropometric characteristics and body composition between rugby players of national team of Montenegro and national team of Bulgaria“ (Malovic, 2018), „Relationship between arm span measurements and body height in Berane“
(Mitrovic, 2018), „Differnces in anthropomeric characteristic among junior soccer and basketball players" (Spaic, Vukasevic, \& Masanovic, 2018), „Relationship Between Arm Span Measurements and Body Height in Tivat" (Radulovic \& Kovacevic, 2018), „Meta analysis of scientific papers on effects of motor skills in the basketball published in the Journal Sport Mont from 2006 to 2018“ (Vasiljevic, 2018), „Sport-specific morphology profile: „Comparative study of morphological characteristics and body compositions between elite basketball players from different regions" (Masanović, Vukotic, \& Vukasevic, 2018), "Meta-analysis of scientific papers in the field of motor skills from volleyball published in the Journal Sport Mont 2006-2016“ (Zoric, 2018), „Differences in anthropometric characteristic among junior soccer and volleyball players" (Masanovic, Bjelica, \& Corluka, 2019), „Differences in anthropometric characteristics among junior basketball and volleyball players“ (Pasa, Vukasevic, \& Masanovic, 2019), „Comparative study of motor ability between basketball players from second leagues from Montenegro and Serbia (Vukasevic, Mitrovic, Zivanovic, \& Masanovic, 2019), „Anthropometric measures and body composition of soccer players of Montenegro and Kosovo (Bjelica, Gardasevic, Vasiljevic, Sermaxhaj, \& Arifi, 2019), „Differences in anthropometric measures of footballers, cup winners of Montenegro and Kosovo" (Gardasevic, Bjelica, Vasiljevic, Arifi, \& Sermaxhaj, 2019), „Comparative analysis of anthropomtric characteristics between athlets of different orientation, basketball and handball" (Vukotic \& Georgiev, 2019), „Comparative analysis of anthropometric characteristics between athlets of differnt orientation“ (Vukotic \& Georgiev, 2019) $i$ „Anthropometric indices as indicator of obesity of children from elementary school in Montenegro" (Malovic, 2019).

Radovi objavljeni u JASPE iz oblasti sportskog marketinga su sledeći: „Attitudes of Turkish consumers toward advertising through sport among the frequency of watshing sports events" (Masanovic, Zoric, \& Gardasevic, 2017), „Attitudes of Turkish consumers toward advertising through sport among the question how often consumes purchase sporting goods" (Zoric, Masanovic, \& Gardasevic, 2017), „Attitudes of Turkish consumers toward advertising through sport among the question how often they paticipate in sports activities" (Gardasevic, Zoric, \& Masanovic, 2017), „Attitudes of Montenegrin consumers toward advertising through sport among the frequency of watching sports events" (Masanovic, Zoric, \& Gardasevic, 2018), „Attitudes of Montenegrin consumers toward advertising through sport among the question how often they participate in sports activities" (Gardasevic, Zoric, \& Masanovic, 2018), "Attitudes of Montenegrin consumers toward advertising through sport among the question how often consumers purchase sporting goods“ (Zoric, Mašanovic, \& Gardasevic, 2018), "Attitudes of consumers from the Mostar canton in Bosnia and Hercegovina toward advertising through sport among the question how often consumers purchase sporting goods" (Bjelica, Gardasevic, \& Corluka, 2018), „Attitudes of consumers from the Mostar canton in Bosnia and Hercegovina toward advertising through sport among the question how often they participate in sports activities" (Corluka, Bjelica, \& Vukotic, 2019), „Attitudes of consumers from the Mostar canton in Bosnia and Hercegovina toward advertising through sport among the frequency of watching sports events" (Vukotic, Corluka, \& Masanovic, 2018), „Attitudes of consumers from the Sarajevo canton in Bosnia and Hercegovina toward advertising through sport among the question how often consumers purchase spor- 
ting goods“ (Zoric, Gardaševic, \& Bajramovic, 2018), „Attitudes of consumers from the Sarajevo canton in Bosnia and Hercegovina toward advertising through sport among the question how often they participate in sports activities" (Gardasevic Bajramovic, \& Masanovic, 2018), „Attitudes of consumers from the Sarajevo canton in Bosnia and Hercegovina toward advertising through sport among the frequency of watching sports events“ (Bajramovic, Zoric, \& Masanovic, 2018). U 2018. godini, ovim istraživanjem obuhvaćeni su i građani glavnog grada Crne Gore: „Attitudes of consumers from Podgorica toward advertising through sport among the question how often they participate in sports activities" (Kovacevic, Milosevic,\& Masanovic, 2018), „Attitudes of consumers from Podgorica toward advertising through sport among the question how often consumers purchase sporting goods" (Djurisic, Perovic, \& Masanovic, 2018), „Attitudes of consumers from Podgorica toward advertising through sport among the frequency of watching sports events" (Milovic, Corluka, \& Masanovic, 2018). Slična analiza je obuhvatila Autonomne pokrajine Vojvodine u Srbiji: „Attitudes of consumers from University of Novi Sad toward advertising through sport among the frequency of watching sports events" (Molnar, Masanovic, \& Bjelica, 2018), „Attitudes of consumers from University of Novi Sad toward advertising through sport among the question how often they participate in sports activities“ (Bjelica, Gusic, \& Maksimovic, 2018), „Attitudes of consumers from University of Novi Sad toward advertising through sport among the question how often consumers purchase sporting goods (Milosevic, Bjelica, \& Matic, 2018), „Attitudes of consumers from Subotica toward advertising through sport among the frequency of watching sports events" (Sekulic, Milosevic, \& Vukotic, 2018), „Attitudes of consumers from Subotica toward advertising through sport among the question how often consumers purchase sporting goods" (Masanović, Georgiev, \& Sekulic, 2018), „Attidudes of consumers from
Educons University toward advertising through sport among the frequency of watching sports events" (Stupar, Gardasevic, \& Masanovic, 2018) i „Attitudes of consumers from Educons University toward advertising through sport among the question how often they participate in sports activities" (Gardasevic, Stupar, Maksimovic, 2018).

Analizom sadržaja objavljenih radova i nihovom klasifikacijom, autori su se bavili kroz sljedeće radove: „Analysis of the content of published articles in the Journal Sport Mont in 2006“ (Vukotic, 2018), „Content analysis of scientific articles from issues published in Sport Mont Journal in 2004" (Mitrovic, 2018), „Content analyses of scientific articles from issues published in Sport Mont Journal 2012“ (Radulovic, 2018), „Meta-analysis original scientific papers in the field of swimming and water polo published in Sport Mont from 2003 to $2018^{\text {“ }}$ (Vukotic, 2018), „Meta-analysis of scientific papers on effects on motor skills in the basketball published in the Journal Sport Mont from 2006 to 2018 (Vasiljevic, 2018) i „Meta-analysis of scientific papers in the field of motor skills from volleyball published in the Journal Sport Mont 2006-2016“ (Zoric, 2018).

U kategoriji ostali radovi spadaju sledeći radovi: „Repulsions ball in table tennis“ (Bjelica, Vukotic, \& Gardasevic, 2018), „The dependence of repulsion tennis ball from the air pressure in it" (Bjelica, Bubanja, \& Gardasevic, 2018), „Meta-anlysis of scientific papers in the field of sports training published in the Journal Sport Mont in 2016“ (Vukotic, 2018), „Evaluation of the physical activity level of elderly women in the canton of Sarajevo in Bosnia and Hercegovina" (Bajramovic, Bjelica, Talovic, Alic, \& Likic, 2018), „Differences in the attitudes of fourth grade pupils of the elementary school according to the teaching of physical education in terms of gender" (Dragutinovic i Mitrovic, 2019) i Meta-analyze of the scientific papers on the sport ball repulsion depending on the air pressure within" (Gardasevic, 2019).

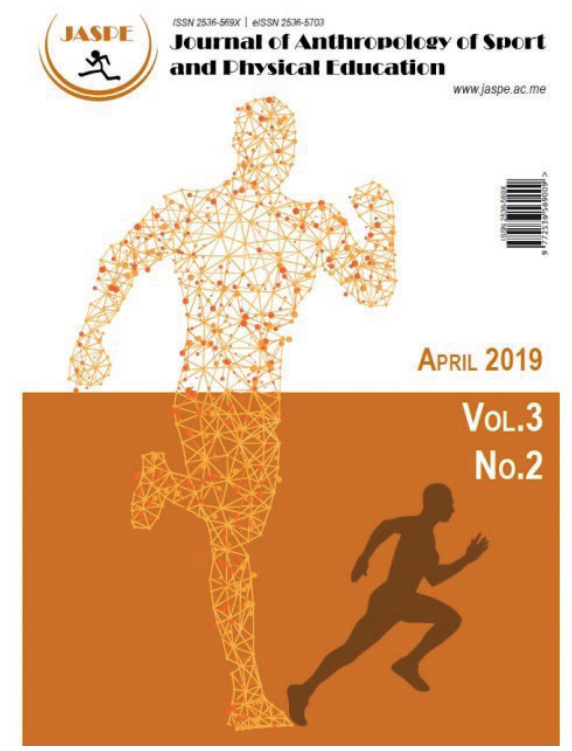

Slika 1. Časopis JASPE Vol. 3 No. 2 (2019)

\section{Diskusija}

U ovom radu, metodom analize sadržaja, naučni radovi predavača sa Fakulteta za sport i fizičko vaspitanje iz Jaspe-a klasifikovani su po oblastima. Ukupno je bilo 69 radova, od čega 35 iz oblasti Antropologije, 22 iz oblasti Sportskog marketinga, šest iz oblasti Analize sadržaja i šest ostalih radova.
Antroplogija je veoma opširna oblast, koja pruža mogućnosti da se intezivnije i na inovativniji način istraži čovjek, pa ne čudi da je više od polovine objavljenih radova baš iz ove oblasti. Poznato je da se mnogo novca danas okreće u sportu, pa je oblast sportskog marketinga izuzetno važna, kako bi se stekla znanja o njegovom upravljanju. Iako u Crnoj Gori možda još 
uvijek nema dovoljno prostora za razvoj sportskog marketinga, klubovi bi trebali pratiti svjetske tendove i uložiti svoje napore $\mathrm{u}$ marketing, budući da je to jedini način za opstanak $\mathrm{u}$ današnjem poslovnom društvu. Analizama sadržaja objavljenih radova omogućen je pregled različitih radova, te njihova kvalitativna i kvantitativna analiza. U ovom slučaju autori su analizirali radove iz časopisa JASPE, što nam može pružiti uvid u teme koje interesuju predavače sa Fakulteta za sport i fizičko vaspitanje u Nikšiću. Ostali radovi donose značajne podatke iz oblasti tenis, stoni tenis, fizčka aktivnost starijih osoba, i na kraju iz oblasti sporstkog treniga, koja je veoma značajna kako za sportiste tako i za sportske radnike, jer obogaćuje praksu i na taj način omogućava postizanje vrhunskih sportskih rezultata. Kvalitetan predavač i sportski radnik mora pratiti tokove istraživanja i nauke, odnosno, mora biti upoznat sa najnovijim dešavanjima i inovacijama u svijetu sporta i fizičke kulture, a ova studija budućim istraživačima u tome može pomoći.

\section{Acknowledgements}

There are no acknowledgements.

\section{Conflict of Interest}

The authors declare that there are no conflicts of interest.

Received: 10 May 2019 | Accepted: 11 June 2019| Published: 4 July 2019

\section{References}

Bajramovic, I., Bjelica, D., Talovic, M., Alic, H., \& Likic, S. (2018). Evaluation of the Physical Activity Level of of Elderly Women in the Canton of Sarajevo in Bosnia and Hercegovina. Journal of Anthropology of Sport and Physical Education, 2(3), 33-36.

Bajramovic, I., Zoric, G., \& Masanovic, B. (2018). Attitudes of Consumers from the Sarajevo Canton in Bosnia and Hercegovina toward Advertising through Sport among the Frequency of Watching Sports Events. Journal of Anthropology of Sport and Physical Education, 2(2), 43-47.

Bjelica, D., Bubanja, M., \& Gardasevic, J. (2018). The Dependence of Repulsion Tennis Ball from the Air Pressure in it. Journal of Anthropology of Sport and Physical Education, 2(3), 77-82.

Bjelica, D., Gardasevic, J., \& Corluka, M. (2018). Attitudes of Consumers from the Mostar Canton in Bosnia and Hercegovina toward Advertising through Sport among the Question how often Consumers purchase Sporting Goods. Journal of Anthropology of Sport and Physical Education, 2(2), 3-7.

Bjelica, D., Gardasevic, J., \& Vasiljevic, I. (2018). Differnces in the Morphological Characteristic and Body Composition of Football Players FC Sutjeska and FC Mladost in Montenegro. Journal of Anthropology of Sport and Physical Education, 2(2), 31-35.

Bjelica, D., Gardasevic, J., Vasiljevic, I., \& Corluka, M. (2018). Body Composition and Anthropometric Measures of Footballers, Cup Winners of Montenegro and Bosnia and Hercegovina. Journal of Anthropology of Sport and Physical Education, 2(3), 3-7.

Bjelica, D., Gardasevic, J., Vasiljevic, I., Sermaxhaj, S., \& Arifi, F. (2019). Anthropometric Measures and Body Composition of Soccer Players of Montenegro and Kosovo. Journal of Anthropology of Sport and Physical Education, 3(2), 29-34

Bjelica, D., Gusic, M., \& Maksimovic, N. (2018). Attitudes of Consumers from University of Novi Sad toward Advertising through Sport among the Question how Often they Participate in Sports Activities. Journal of Anthropology of Sport and Physical Education, 2(3), 15-20.

Bjelica, D., Vukotic, M., \& Gardasevic, J. (2018). Repulsions Ball in Table Tennis. Journal of Anthropology of Sport and Physical Education, 2(3), 15-19.

Bubanja, M. (2018). Body Height and Its Assessment by Using the Arm Span of Adolescents From the Montenegrin Municipalities of Berane and Pljevlja. Journal of Anthropology of Sport and Physical Education, 2(3), 49-53.

Bubanja, M. (2018). Body Height and Its Estimation Utilizing Arm Span Measurements in Adolescents From Nothern Region in Montenegro. Journal of Anthropology of Sport and Physical Education, 2(3), 67-71.

Corluka, M., \& Vasiljevic, I. (2018). Differnces in the Morphological Characteristics and Body Composition of Football Players in Montenegro. Journal of Anthropology of Sport and Physical Education, 2(1), 3-7.
Corluka, M., Bjelica, D., \& Vukotic, M. (2018). Attitudes of Consumers from the Mostar Canton in Bosnia and Hercegovina toward Advertising through Sport among the Question how Often they Participate in Sports Activities. Journal of Anthropology of Sport and Physical Education, 2(2), 9-13.

Djurisic, V., Perovic, Dj., \& Masanovic, B. (2018). Attitudes of Consumers from Podogorica toward Advertising through Sport among the Question how Often Consumers Purchase Sporting Goods. Journal of Anthropology of Sport and Physical Education, 2(2), 55-60.

Dragutinovic, K., \& Mitrovic, M. (2019). Differences in the attitudes of fourth grade pupils of the elementary school according to the teaching of physical education in terms of gender. Journal of Anthropology of Sport and Physical Education, 3(1), 29-34. doi: 10.26773/ jaspe. 190106

Gardasevic, J. (2019). Meta-Analyze of the Scientific Papers on the sport balls Repulsion Depending on the Air Pressure within. Journal of Anthropology of Sport and Physical Education, 3(1), 55-57.

Gardasevic, J., Bajramovic, I., \& Masanovic, B. (2018). Attitudes of Consumers from Sarajevo Canton in Bosnia and Hercegovina toward Advertising through Sport among the Question how Often they Participate in Sports Activities. Journal of Anthropology of Sport and Physical Education, 2(2), 37-41.

Gardasevic, J., Bjelica, D., Popovic, S., Vasiljevic, I., \& Milosevic, Z. (2018) Differences in the Morphological Characteristics and Body Composition of Football players FC Buducnost and FC Mladost in Montenegro. Journal of Anthropology of Sport and Physical Education, 2(1), 51-55.

Gardasevic, J., Bjelica, D., Vasiljevic, I., Arifi, F., \& Sermaxhaj, S. (2019). Differences in Anthropometric Measures of Footballers, Cup Winners of Montenegro and Kosovo. Journal of Anthropology of Sport and Physical Education, 3(1), 23-27.

Gardasevic, J., Bjelica, D., Vasiljevic, I., Sermaxhaj, S., \& Arifi, F. (2018). Differences in the Morphological Characteristics and Body Composition of Football Players FC Trepca ' 89 and FC Prishtina in Kosovo. Journal of Anthropology of Sport and Physical Education, 2(3), 105-109.

Gardasevic, J., Stupar, D., \& Maksimovic, N. (2018). Attitudes of Consumers from Educons University toward Advertising through Sport among the Question how Often they Participate in Sports Activities. Journal of Anthropology of Sport and Physical Education, 2(3), 137-142.

Gardasevic, J., Zoric, G., \& Masanovic, B. (2017). Attitudes of Turkish Consumers toward Advertising Through Sport among the Question how Often they Participate in Sports Activities. Journal of Anthropology of Sport and Physical Education, 1(1), 23-27.

Gardasevic, J., Zoric, G., \& Masanovic, B. (2018). Attitudes of Montenegrin Consumers Toward Advertising Through Sport among the Question How Often They Participate in Sports Activities. Journal of Anthropology of Sport and Physical Education, 2(1), 15-19.

Kovacevic, D., Milosevic, Z., \& Masanovic, B. (2018). Attitudes of Consumers from Podgorica toward Advertising through Sport among the Question how Often they Participate in Sports Activities. Journal of Anthropology of Sport and Physical Education, 2(2), 61-65.

Kovacevic, M., \& Radulovic, J. (2018). Relationship Between Arm Span Measurements and Body Height in Plav. Journal of Anthropology of Sport and Physical Educatio, 2(4), 27-31.

Malovic, P. (2018). Differences in Anthropometric Characteristics and Body Compositions between Rugby Players of National Team of Montenegro and National Team of Bulgaria. Journal of Anthropology of Sport and Physical Education, 2(3), 65-69.

Malovic, P. (2019). Anthropometric Indices as Indicators of Obesity of Children from Elementary School in Montenegro. Journal of Anthropology of Sport and Physical Education, 3(2), 43-47.

Masanovic, B. (2017). Relationship between Arm Span Measurements and Body Height in Dinaric Alpes Population: a Systematic Review. Journal of Anthropology of Sport and Physical Education, 1(1), 33-37.

Masanovic, B., Bjelica, D., \& Corluka, M. (2019). Differences in Anthropometric Characteristics among Junior Soccer and Volleyball Players. Journal of Anthropology of Sport and Physical Education, 3(2), 9-13.

Masanovic, B., Georgiev, G., \& Sekulic, N. (2018). Attitudes of Consumers from Subotica toward Advertising through Sport among the Question how Often Consumers purchase Sporting Goods. Journal of Anthropology of Sport and Physical Education, 2(3), 99-104.

Masanovic, B., Spaic, S., \& Vukasevic, V. (2018). Comparative Study of Anthropometric Measurements and Body Composition between Different Levels od Competation. Journal of Anthropology of Sport and Physical Education, 2(3), 21-26.

Masanovic, B., Vukcevic, A., \& Spaic, S. (2018). Sport-Specific Morphology Profile: Differences in Anthropometric Characteristics between Elite Soccer and Basketball Players. Journal of Anthropology of Sport and Physical Education, 2(3), 43-47. 
Masanovic, B., Vukotic, M., \& Vukasevic, V. (2018). Comparative study of Morphological Characteristics and Body Compositions between Elite Basketball Players from Differnt Regions. Journal of Anthropology of Sport and Physical Education, 2(3), 103-107.

Masanovic, B., Zoric, G., \& Gardasevic, J. (2017). Attitudes of Turkish Consumers toward Advertising through Sport among the Frequency of Watching Sports Events. Journal of Anthropology of Sport and Physical Education, 1(1), 3-7.

Masanovic, B., Zoric, G., \& Gardasevic, J. (2018). Attitudes of Montenegrin Consumers Toward Advertising through Sport among the Frequency of Watching Sports Events. Journal of Anthropology of Sport and Physical Education, 2(1), 9-13.

Milosevic, Z., Bjelica, D., \& Matic, R. (2018). Attitudes of Consumers from University of Novi Sad toward Advertising through Sport among the Ques tion how often Consumers purchase Sporting Goods. Journal of Anthropology of Sport and Physical Education, 2(3), 49-54.

Milosevic, Z., Vukotic, M., \& Stupar, D. (2018). Attitudes of Consumers from Educons University toward Advertising through Sport among the Question how Often Consumers purchase Sporting Goods. Journal of Anthropology of Sport and Physical Education, 2(3), 159-164.

Milovic, N., Corluka, M., \& Masanovic, B. (2018). Attitudes of Consumers from Podgorica toward Advertising through Sport among the Frequency of Watchin Sports Events. Journal of Anthropology of Sport and Physical Education, 2(2), 71-76.

Mitrovic, M. (2018). Content Analyses of Scientific Articles from Issues Published in Sport Mont Journal in 2004. Journal of Anthropology of Sport and Physical Education, 2(2), 77-81.

Mitrovic, M. (2018). Relationship Between Arm Span Measurements and Body Height in Pljevlja. Journal of Anthropology of Sport and Physical Education 2(3), 9-13.

Mitrovic, M. (2018). Relationship Between Arm Span Measurements and Body Height in Berane. Journal of Anthropology of Sport and Physical Education, 2(3), 71-75.

Mitrovic, M. (2018). Self-Reported and Objectively Measured Physical Activity of Males from 50 to 69 Years. Journal of Anthropology of Sport and Physical Education, 2(2), 99-101.

Molnar, S., Masanovic, B. \& Bjelica, D. (2018). Attitudes of Consumers from University of Novi Sad toward Advertising through Sport among the Frequency of Watching Sports Events. Journal of Anthropology of Sport and Physical Education, 2(3), 9-14.

Pasa, Y. K., Vukasevic, V., \& Masanovic, B. (2019). Differences in Anthropometric Characteristics among Junior Basketball and Volleyball Players. Journal of Anthropology of Sport and Physical Education, 3(1), 35-39.

Radulovic, J. (2018). Content Analyses of Scientific Articles from Issues Published in Sport Mont Journal in 2012. Journal of Anthropology of Sport and Physical Educatio, 2(2), 115-120.

Radulovic, J. (2018). Self-Reported and Objectively Measured Physical Activity of Males from 50 to 69 Years Old.

Radulovic, J., \& Kovacevic, M. (2018). Relationship Between Arm Span Measurements and Body Height in Tivat. Journal of Anthropology of Sport and Physical Educatio, 2(4), 93-97.

Sekulic, N., Milosevic, Z., \& Vukotic, M. (2018). Attitudes of Consumers from Subotica toward Advertising through Sport among the Frequency of Watching Sports Events. Journal of Anthropology of Sport and Physical Education, 2(3), 55-60.

Spaic, S., Vukasevic, V.,\& Masanovic, B. (2018). Differences in Anthropometric Characteristics among Junior Soccer and Basketball Players. Journal of Anthropology of Sport and Physical Education, 2(3), 89-92.

Stupar, D., Gardasevic, B., \& Masanovic, B. (2018). Attitudes of Consumers from Educons University toward Advertising through Sport among the Frequency of Watching Sports Events. Journal of Anthropology of Sport and Physical Education, 2(3), 131-136.

Vasiljevic, I. (2017). Meta-Analyze of the Scientific Papers on the Effects of the Preparation Period on the Basic Motor Skills of the Cadet Football Players. Journal of Anthropology of Sport and Physical Education, 1(1), 29-32.
Vasiljevic, I. (2018). Meta-Analysis of Scientific Papers on Effects on Motor Skills in the Basketball Published in the Journal Sport Mont from 2006 to 2018. Journal of Anthropology of Sport and Physical Education, 2(3), 99-101.

Vasiljevic, I. (2018). Meta-Analyze of the Scientific Papers on the Effects of the Preparation Period on the Situational Motor Skills of the Cadet Football Players. Journal of Anthropology of Sport and Physical Education, 2(2), 6770.

Vukasevic, V., Mitrovic, M., Zivanovic, N., \& Masanovic, B. (2019). Comparative Study of Motor Ability between Basketball Players from Secon Leagues in Montenegro and Serbia. Journal of Anthropology of Sport and Physical Education, 3(1), 13-17.

Vukasevic, V., Spaic, S., \& Masanovic, B. (2018). Comparative Study of Anthropometric Measurements and Body Composition between Basketball Players the First and Second League in Montenegro. Journal of Anthropology of Sport and Physical Education, 2(3), 61-65.

Vukasevic, V., Vukotic, M., \& Masanovic, B. (2018). Comparative Study od the Morphological Characteristics and Body Compositions between Basketball Players from Second Leagues in Montenegro and Serbia. Journal of Anthropology of Sport and Physical Education, 2(3), 21-25.

Vukotic, M. (2018). Analysis of the Content of Published Articles in the Journal Sport Mont 2006. Journal of Anthropology of Sport and Physical Education, 2(1), 31-39.

Vukotic, M. (2018). Body Height and Its Estimation Utilizing Arm Span Measurements in Male and Female Adolescents from Nothern Region in Montenegro. Journal of Anthropology of Sport and Physical Education, 2(3), 73-77.

Vukotic, M. (2018). Body Height and Its Estimation Utilizing Arm Span Measurements in Male and Female Adolescents from Danilograd and Cetinje. Journal of Anthropology of Sport and Physical Education, 2(3), 117-121.

Vukotic, M. (2018). Meta-Analysis of the Original Scientific Papers in the Fields of Swimming and Water polo Published in Sport Mont from 2003 to 2018 Journal of Anthropology of Sport and Physical Education, 2(3), 61-64.

Vukotic, M. (2018). Meta-Analysis of the Scientific Papers in the Fields of Sports Training Published in the Journal Sport Mont 2016. Journal of Anthropology of Sport and Physical Education, 2(1), 47-49.

Vukotic, M. (2018). The importance of physical activity and fitness progams in older people: a Systematic review. Journal of Anthropology of Sport and Physical Education, 2(3), 37-41.

Vukotic, M., \& Geogriev, G. (2019). Comparative Analysis of Anthropometric Characteristics between Ahtlets of Different Orientation, Basketball and Handball. Journal of Anthropology of Sport and Physical Education, 3(2), 19-23.

Vukotic, M., \& Georgiev, G. (2019). Comparative Analysis of Anthhropometric Characteristics between athlets of Different Orientation. Journal of Anthropology of Sport and Physical Education, 3(1), 41-45.

Vukotic, M., Corluka, M., \& Masanovic, B. (2018). Attitudes of Consumers from the Mostar Canton in Bosnia and Hercegovina toward Advertising through Sport amon the Frequency of Watching Sports Events. Journal of Anthropology of Sport and Physical Education, 2(2), 19-23.

Vukotic, M., Corluka, M., Vasiljevic, I., \& Bubanja, M. (2018). Differences in the Morphological Characteristics and Body Compositions of Handball Players WHC Levalea in Montenegro and WHC Grude in Bosnia and Hercegovina. Journal of Anthropology of Sport and Physical Education, 2(2), 49-53.

Zoric, G. (2018). Meta-Analysis of Scientific Papers in the Field of Motor Skills from Volleyball Published in the Journal Sport Mont 2006-2016. Journal of Anthropology of Sport and Physical Education, 2(3), 109-112.

Zoric, G., Gardasevic, J., \& Bajramovic, I. (2018). Attitudes of Consumers from the Sarajevo Canton in Bosnia and Hercegovina toward Advertising through Sport among the Question how often Consumers purchase Sporting Goods. Journal of Anthropology of Sport and Physical Education, 2(2), 25-29.

Zoric, G., Masanovic, B., \& Gardasevic, J. (2017). Attitudes of Turkish Consumers toward Advertising through Sport among the Question how often Consumers purchase Sporting Goods. Journal of Anthropology of Sport and Physical Education, 1(1), 17-21. 